\title{
New Forms of Place-Making and Public Space in Contemporary Urban Development in Seoul, South Korea
}

\author{
Hee Sun (Sunny) Choi \\ Lecturer, Landscape Architecture, Hong Kong Design Institute, Hong Kong, China \\ Email: sunny@choi-comer.com
}

How to cite this paper: Choi, H. S. (Sunny) (2017). New Forms of Place-Making and Public Space in Contemporary Urban Development in Seoul, South Korea. Current Urban Studies, 5, 332-347. https://doi.org/10.4236/cus.2017.53018

Received: July 21, 2017

Accepted: August 29, 2017

Published: September 1, 2017

Copyright $\odot 2017$ by author and Scientific Research Publishing Inc. This work is licensed under the Creative Commons Attribution International License (CC BY 4.0).

http://creativecommons.org/licenses/by/4.0/

\section{(c) (i) Open Access}

\begin{abstract}
Place-making and its evolving role in urban design has become a major issue in setting the $21^{\text {st }}$ century urban development agenda. A key aspect of this within South East and East Asia in particular is an apparent tension between global aspirations and local tradition in emerging states such as China, South Korea and Malaysia. The intention of this paper is to provide a better understanding of how new place making can be incorporated in contemporary urban development, particularly within this South East/East Asian context, so that the needs of local cultures can be sustained and developed, whilst acknowledging the desire of emerging states to gain international respect and recognition. The focus of this research is on exploring how these two views of design - the globally aspirational, and the locally situated and informedmight be reconciled, using the particular context of South Korea and the city of Seoul as a case study.
\end{abstract}

\section{Keywords}

Place-Making, Urban Transformation, Place Identity, Sustainability, Sustainable Social and Cultural Identity

\section{Introduction}

There is now a widely held belief (King, 2004; Werbner, 1998; Appadurai, 1996) that contemporary public space is defined by political, economic and technological advancements, with the issues surrounding public space directly linked to the politics and socio-cultural make-up of the local community, and how the situated histories of places within cities and local society and culture intersect.

Within this context, the majority of recent South East and East Asian urban 
developments can be characterised as market-driven and consequently resulting in a degree of homogeneity in their built form patterns, with a general lack of concern for sustainable place-making and building practice. This has contributed to the degradation of both regional culture and civic society.

In parallel, the issues identified by a number of scholars (McDowell, 1997; Fraser, 1992; Mitchell, 1995; Zukin, 1991) surrounding the commodification and semi-privatisation of public space for commercial benefit are also relevant in relation to the urban and economic growth that is occurring within South East and East Asia.

Considering that, the aim of this paper is to discover how new place making can be incorporated in contemporary development, using the case of Seoul in South Korea. Seoul is chosen as a particular reference case and example of a city with a historic core that has integrated new development on a significant scale, and as such can provide a physical reference for a theoretical review. The question that this paper addresses is how can place making contribute to the retention and evolution of a sustainable built environment?

\section{Methods}

In order to understand the Sejong-ro case study area in Seoul, in relation to the retention and evolution of traditional cultures and the particular kind of place identity that is emerging, information was collected using a variety of methods. The primary method involved a series of semi-structured interviews aimed at gaining a clear insight into the perspectives of different key actors involved in the Sejong-ro project. The interviews focused on building up a comprehensive narrative of their knowledge, experience, and sense of identity and sustainability in new place making. The interviews were conducted with officials from government, local authorities, public and private producers, developers, non-governmental organizations, and residents. Other methods of obtaining information involved direct observations within the field, and gathering archival material such as government documents, newspapers, previous research work and policy documents.

The research employed morphological and typological field surveys. The empirical study in Jongro, Seoul was carried out from April to December, 2012. Using William Whyte's “The Social Life of Small Urban Spaces" (1980) as a key precedent, these research methods provide a means of gaining a deeper insight into practical questions and issues relating to local identity.

21 semi-structured interviews were carried out with key decision makers and those in urban design-related professions to ascertain the value and appreciation of place-identity; two focus group meetings with users and one workshop with urban design students were also part of the enquiry. These interviews were designed to gain feedback from representatives of the four different key actors groups involved with Seoul's development and new town projects in South Korea; government, public/private producers, controllers and consumers (users 
and residents).

\section{Seoul in Retrospect}

Seoul, the capital of South Korea, is situated in the northwest of the country. It is a settlement that has existed for over 2000 years. In the 14th Century it was established as the capital of Joseon, a sovereign state that preceded the formation of Korea. With Japanese colonial rule (1910-1945) came the development of a modernised public infrastructure and increased urbanization across Korea and in Seoul in particular. This evolution is visible in the street patterns of Seoul today, with the northern and southern sides of the city each having a particular morphological character. The southern part of the city that has grown up since the period of Japanese colonial rule has a recognisably rectilinear urban grid, whereas the northern part is more organic and diverse in character, and retains the layout put in place based on the principles of geomancy 600 years ago (see Figure 1).

Since the end of Japanese rule in 1945 Seoul has steadily grown in size as a consequence of urban migration and economic development. As the city has grown it has evolved from a linear city into a polycentric-core (multi-core) city of approximately $600 \mathrm{~km}^{2}$ in size, with a population of 10.5 million people within the city itself, and a population of 23 million within the wider metropolitan area (http://www.seoul.go.kr/)

The historical development of Seoul is thus recognizable in the characteristic building typologies from each period, with the traditional buildings that pre-date the Japanese colonization, the key buildings from the colonial period that have been retained, and the modern architecture that has grown up since Korean independence (see Figure 2).
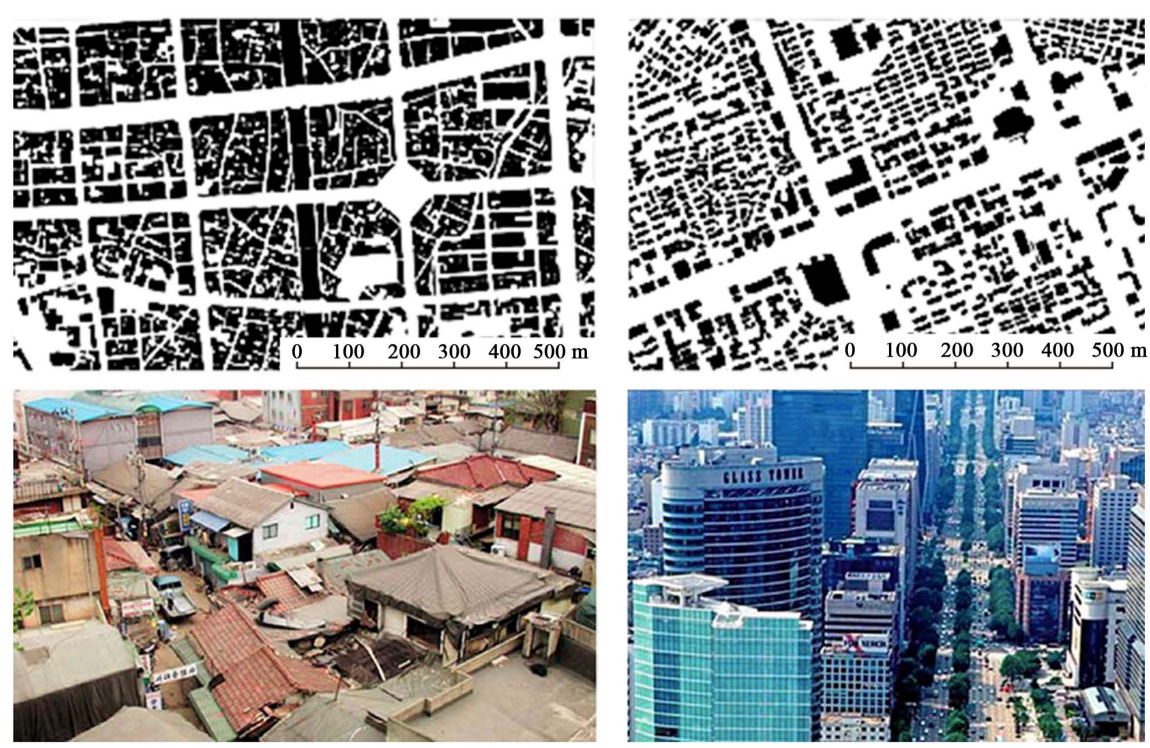

Figure 1. Typology of Seoul in the northern part of the city (on left) and southern part (on right), (source: Seoul City Hall, 2009). 


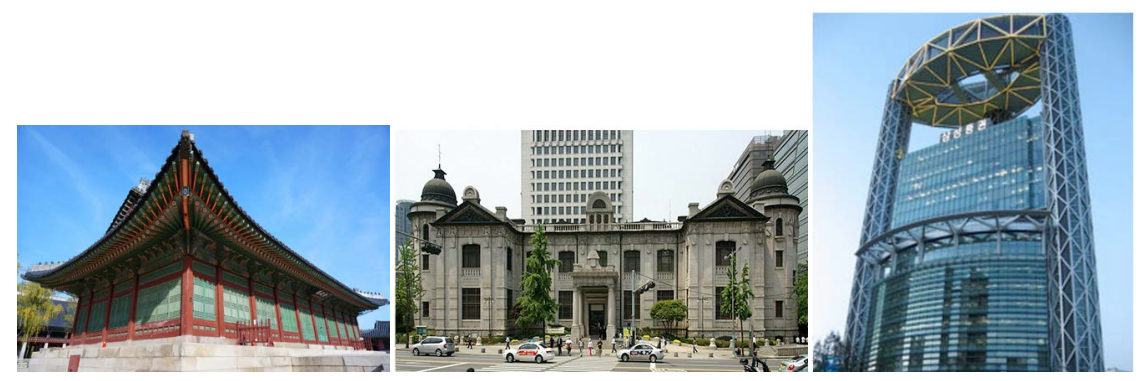

Figure 2. Gyeongbuk Palace, originally constructed from 1395 onwards, (source: Kim, 2013); Bank of Korea, built in 1909, (source: Kernbeisser, 2010); Jongro Tower, built in 1999, (source: Author, 2012).

As described in Seoul urban development by Seon (2003), following the liberation and independence from Japan in 1945, Seoul experienced extremely rapid urban construction that further broke away from the traditional concepts of geomancy and embraced modern designs and international influences. However, detailed research into the history of the urban development of Seoul is hindered by the fact that through the period of Japanese colonization (1910-1945) and the Korean War (1950-1953) most of the historical urban development and policy documents relating to Seoul were burned or destroyed. Consequently the surviving documentation recording how Seoul has changed and developed is limited (Seon, 2003). Currently, only a small number of authors (Seon, 2003; Lee, 1994; Kim, 1991) have published accounts of Seoul's urban development and transformation, based on the limited written history and oral accounts from government officials and private developers.

As international trade with South Korea grew during the period from the 1960s until the mid-1980s, new buildings housing multi-national corporations became a dominant force in shaping and rearranging the urban fabric of central Seoul. These building types in Seoul demonstrate some repetitive contemporary characteristics that typify a commercial approach to built form production influenced by capitalism, globalization and "positivistic technocentric rationality" (Harvey, 1990).

In the context of the urban development of Seoul, this positivism relates to the influence of the Korean mega-industrialists and multi-national companies and their quantitatively proven formulas for economic growth and urban development. A particular characteristic of South Korea is the immense power and influence held by these companies, notably Samsung, LG and Hyundai. Technocentric rationality also relates to industrial and capital accumulation to affect, control and protect the environment (Harvey, 1990). This technocentric approach and the practice of building monuments as symbols of corporate power has characterized Seoul's urban context, combining with the historical monuments symbolic of political and dynamic power. This form of urban development has been analysed by Abel's (1997) theory. His theory refers to the changeability and shifts between different times, places, and people and he uses these 
movements as three chronological terms: "traditional culture", "colonial culture" and "consumerism culture". The current phase of the urban development of Seoul can be classified as the latter of these.

\section{Creation of New Public Space and Erasure of Historic Landmark Buildings}

As part of this urban transformation, new design strategies and urban development concepts were introduced in 2010 for four major new development corridors in the city even more future oriented but rooted yet, each with its own distinct character; the historic corridor, digital media corridor, creative corridor and green corridor (see Figure 3).

This is an attempt by the planning department to utilize a coherent and systematic approach to improve the built environment, in response to a period of growth within the centre of the city that led to a production of the built environment that resulted in the creation of "ambiguous" places of control and consumerism lacking in local identity and a sense of place.

Firstly at the digital media corridor, the urban transformation includes the creation of a new urban culture based on digital media technology within the CBD area of Seoul, aimed at creating a vibrant new urban environment through public and private partnerships fuelled by wireless communication and connectivity, and the regeneration of historic and cultural spaces around heritages sites (see Figure 4 and Figure 5).

The second key axis within the new development plan, and the main focal point of this research, is the Historic Corridor (see Figure 5), centred around Sejong-no (named after Sejong the fourth King of the Joseon Dynasty, "no" meaning street). This wide boulevard is positioned to the south and on axis with the Joseon Dynasty Palace, of Gyeongbokgun. The Joseon Dynasty was the longest standing and most recent of the Dynastic periods in Korean history and the period within which the foundations of Korea were established. Knowing this, when the Japanese colonized Korea in 1910 this site was chosen as the

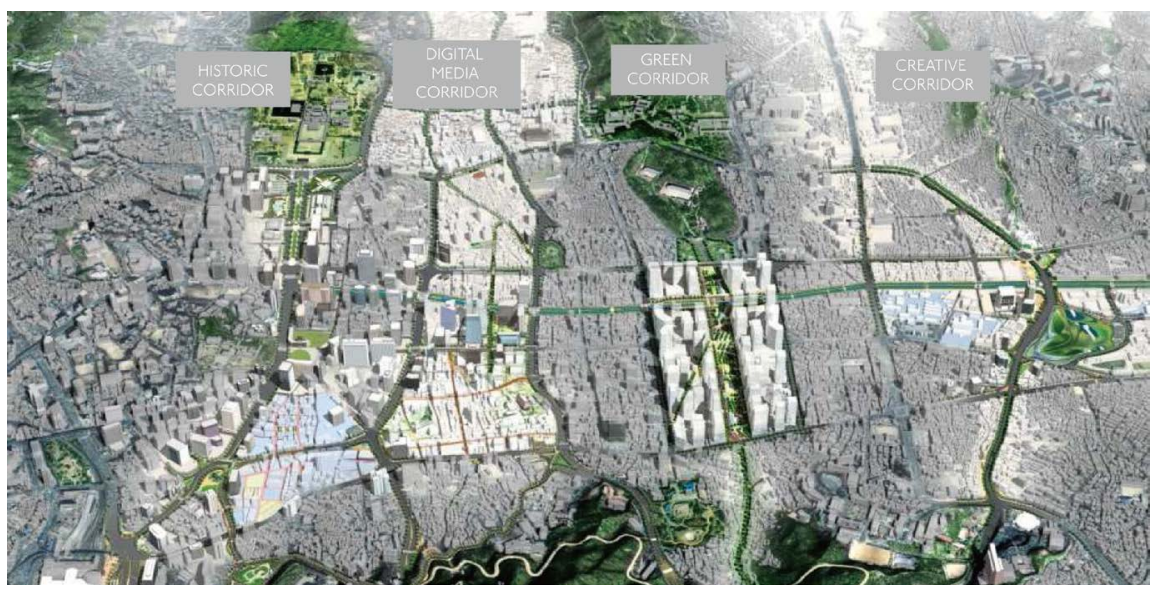

Figure 3. 2010 design strategy (Source: Seoul City Government, 2009). 


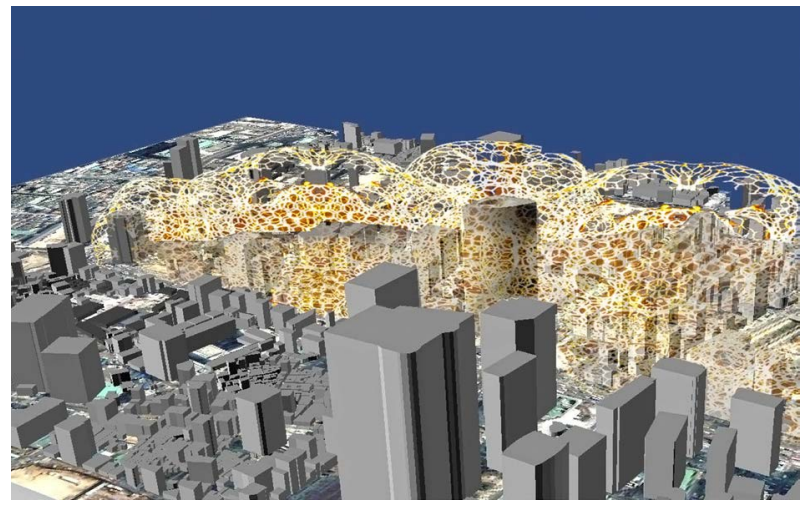

Figure 4. View of Digital Media Corridor (Source: Author, 2012).

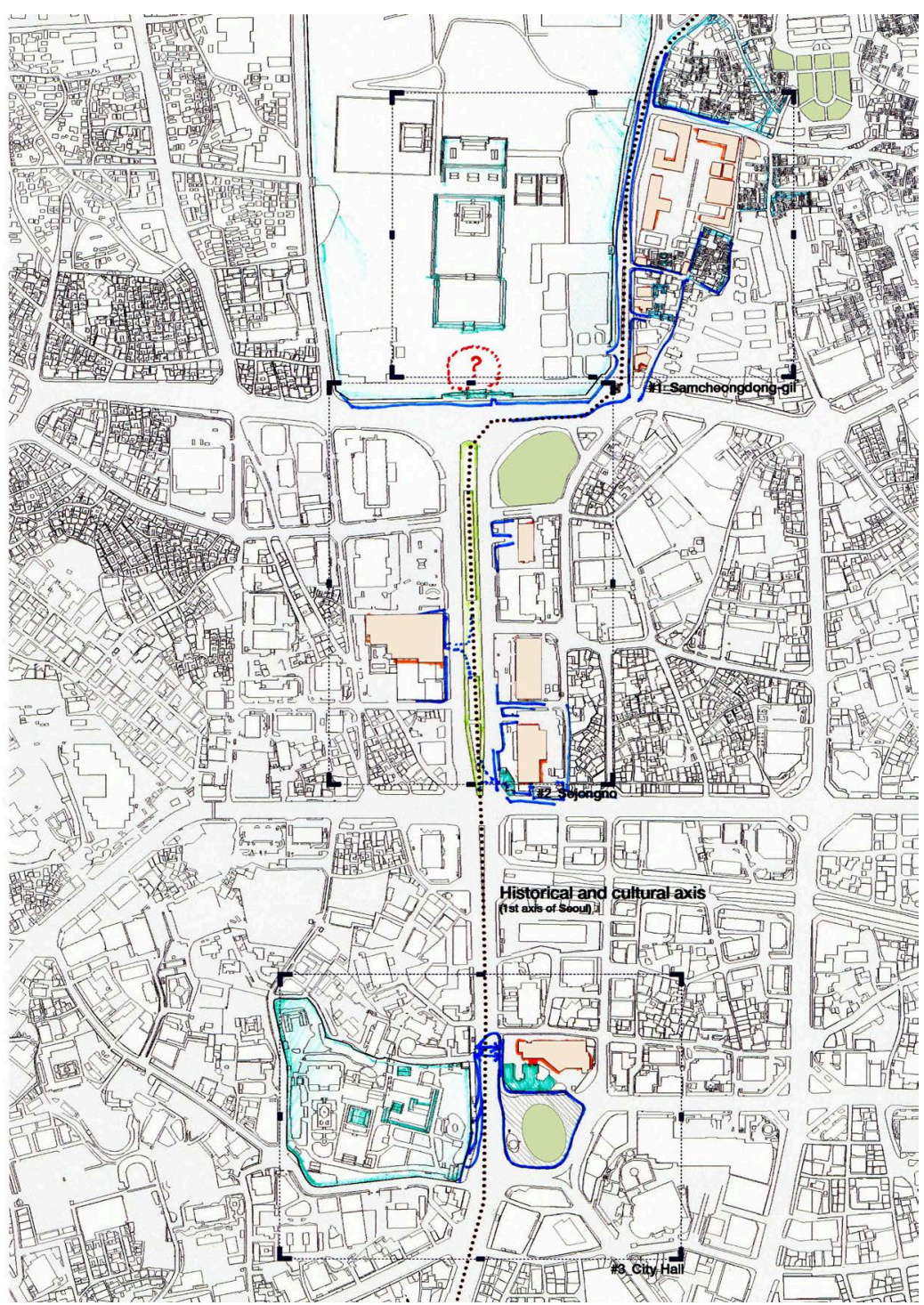

Figure 5. View of Historic Corridor (source: Author, 2012). Note: Historic Corridor with Sejong-no as the principal boulevard running between the informal spatial structure and cultural usage within Samcheong Dong to the north and the heritage sites, City Hall and new public space to the south. 
location of the Governor General Building of Seoul, completed in 1926 and occupied by the Japanese colonial rulers of Korea until the United States received the Japanese surrender from this building at the end of the Second World War in 1945 (Yoo, 2010).

Following this, the building continued as government offices for the Korean Government for a further 40 years, until 1982 when it was converted to a museum and opened to the public. Over this period the building and what it represented continued as a topic of much debate in relation to the modern identity and history of South Korea. In 1996 the Korean Government reached the decision to demolish the building. For many South Koreans, although there were changes of occupation in the intervening years this building continued to symbolize the period of Japanese rule and some welcomed the demolition. But for many others, particularly amongst the younger generation the building was an important landmark. This view was underlined by the focus group meetings and workshop conducted with local users in Seoul; when asked the question what for them symbolised Seoul's identity, a number of participants referred to the former Governor General Building.

Reviewing the process of the decision to demolish the colonial building was partly inspired by the desire to erase the memory of the Japanese colonial era, and partly inspired by a wish to restore the visual symmetry and appearance of the Sejong-no Boulevard, Gate and Palace beyond (see Figure 6).

With the demolition of the Governor General Building at the northern end of Sejong-no complete, the Historic Corridor design proposals include a renovation of the boulevard itself, with the central reservation updated to include water and landscape features and new paving. This boulevard is a destination for tourists and for certain national celebrations when the 8 lanes of traffic are closed, the 600 metre long boulevard is transformed into a 100 metre wide pedestrian processional space (see Figure 7).

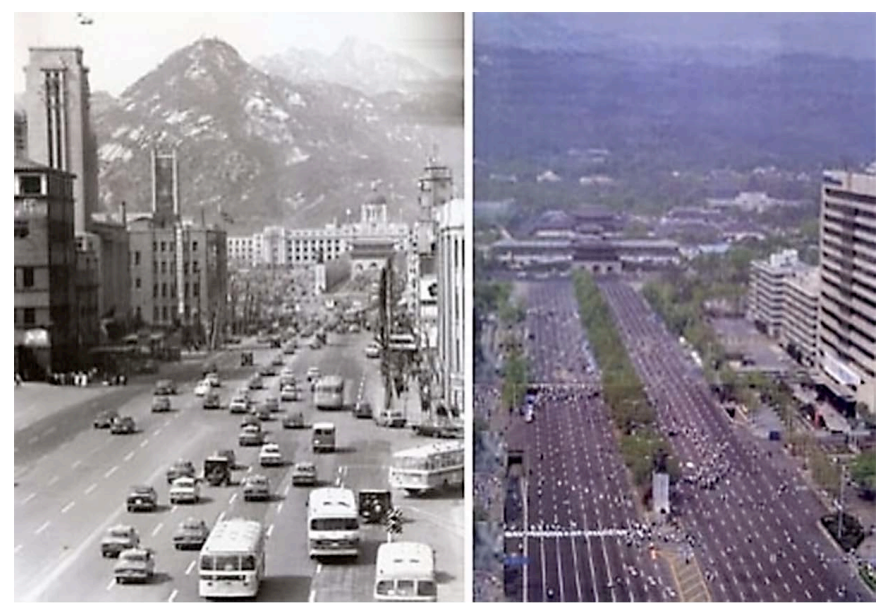

Figure 6. Sejong-no from 1965 (left) showing the domed roof of the Japanese colonial Governor General Building at the northern end. A more recent view of Sejong-no (right) with the building demolished (Park, 2017). 


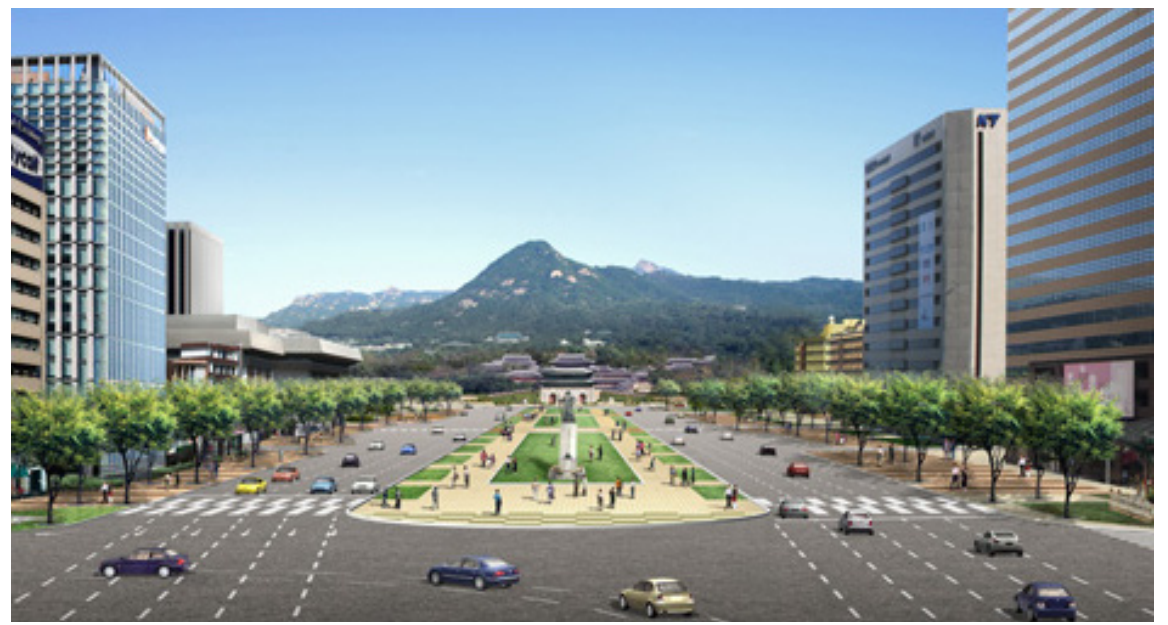

Figure 7. Views of new public space along Sejong-no and Gyeongbok Palace (Source: Yoo, 2010).

This redevelopment, with its focus on the creation of a pedestrian-friendly environment and sustainable environmentally friendly public open space, can be considered as an "eco-cultural" approach to place-making, defined by Abel (1997) as a form of cultural emancipation and a counteraction against the drawbacks of modernized market-led approaches to urban form.

However, as noted by R. King (2009), the erasure of the old traditions in Korean urban development has currently left behind a vacuum in urban development. Using the case study site of Sejong-no in Central Seoul, and considering the arguments put forward by Abel in defining an "eco-culture" that is influenced by market-led approaches and the observations by Ross and others in relation to the urban development of Seoul, the case study research included direct observation of Sejong-no as a means of testing these theories and how they can be operationalized on the ground. This clarified the land use and the architectural typologies that exist within the Sejong-no and Samcheong-dong area. An imposing gateway to Seoul's CBD, the central Boulevard of Sejong-no stands in contrast with the cultural area of small traditional lanes that are set back from the large commercial blocks on the main street. It is within this network of smaller scale streets that a creative and cultural community is growing, full of art galleries and small commercial enterprises, with traditional and contemporary building types that reveal an evolving social and cultural network.

Considering the physical and social aspects within the area, the study highlighted 1) the area within which the evolving creative usage by local artists and galleries is taking place and 2) how this usage is influencing the identity of public space. Figure 5 shows an overall view of Sejong-no and Samcheung-dong, with Figure 8 and Figure 9 providing detailed views and analysis. This mapping analysis taken from survey data and illustrates the way in which the cultural usage and activity is strongest within the Samcheung-dong area, whilst the Northern section of Sejong-no is quiet and practically devoid of cultural activity. 


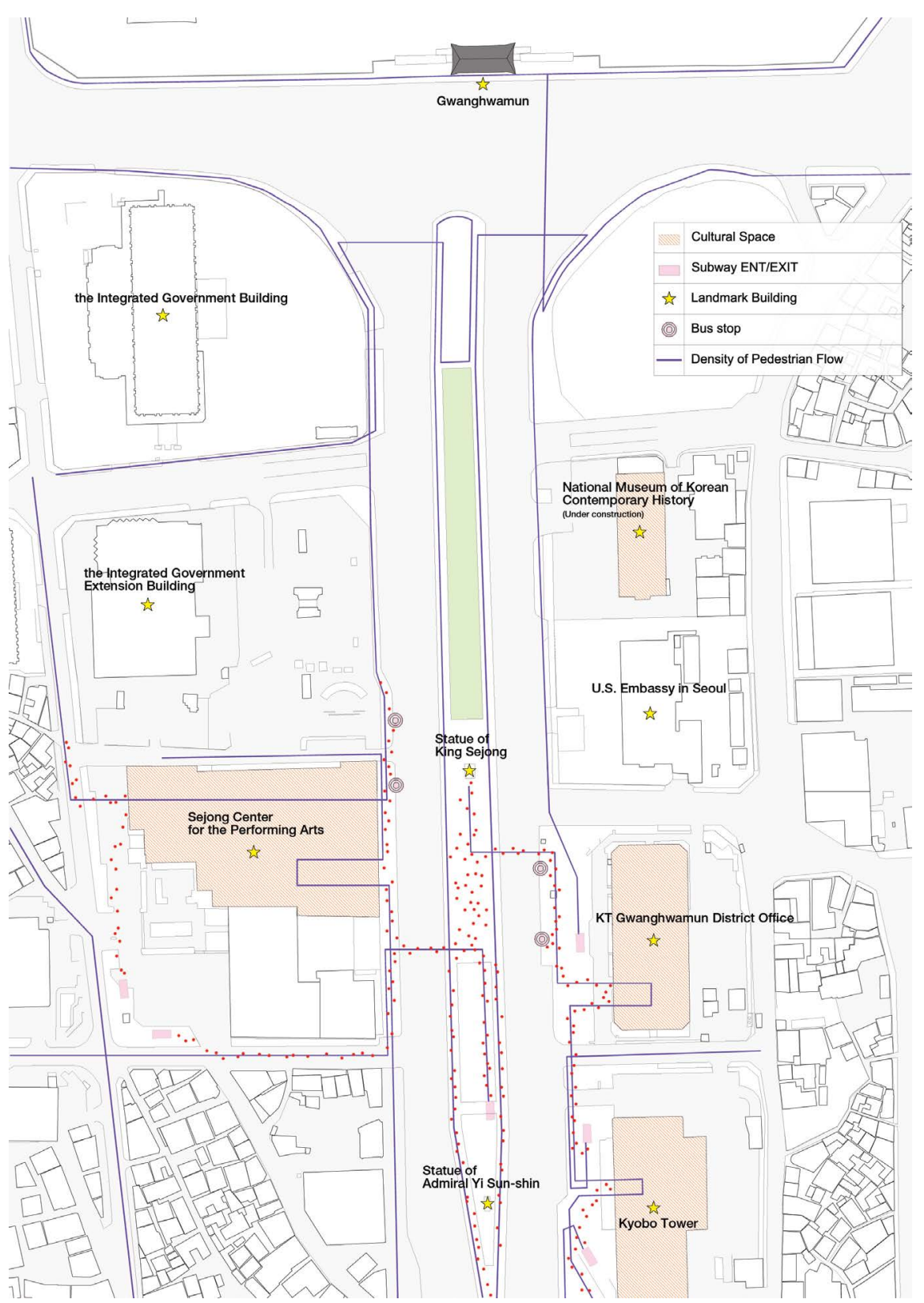

Figure 8. Sejong-no: Spatial analysis with cultural activity (Source: Author, 2012).

The spatio-functional analysis and observations above are supported by street level views taken from the Samcheung-dong and Sejong-no areas (Figure 10 and Figure 11).

The map analysis with site observation focuses in particular on the density and forms of usage within the public space of Sejong-no and Samcheung-dong. These findings illustrate that there is a growth in communal performance and exhibition spaces for artists and their audiences within the smaller streets of Samcheung-dong, together with tourists and other local users. One participant from the interview noted "I prefer the organic nature of these street patterns, 


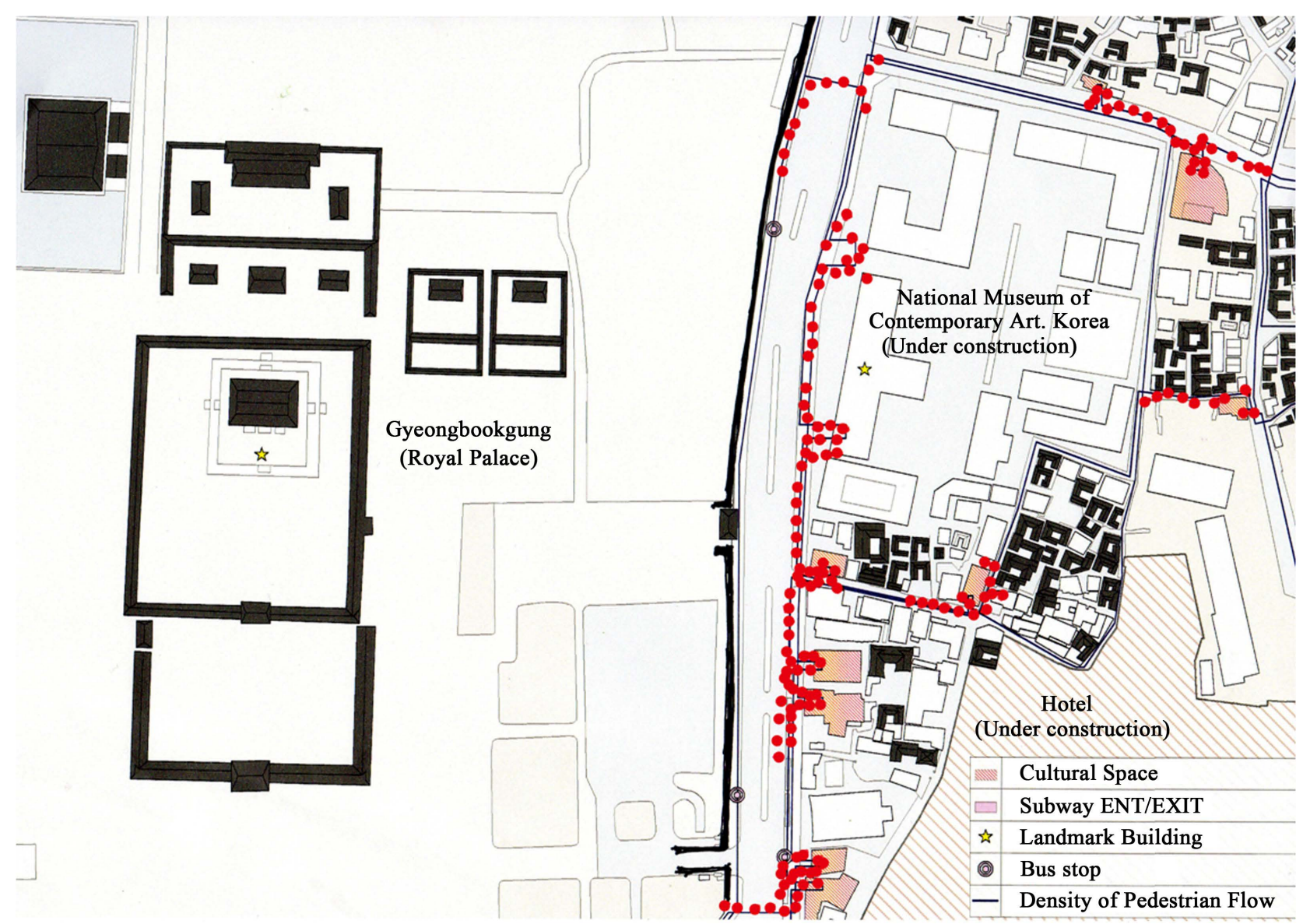

Figure 9. Samcheong-dong: Spatial analysis with cultural activity (Source: Author, 2012).

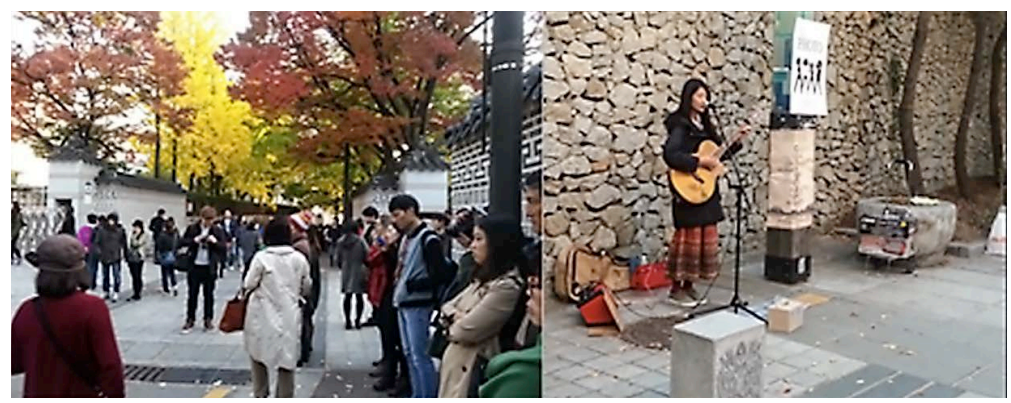

Figure 10. Samcheong-dong (above) (Source: Author, 2012).

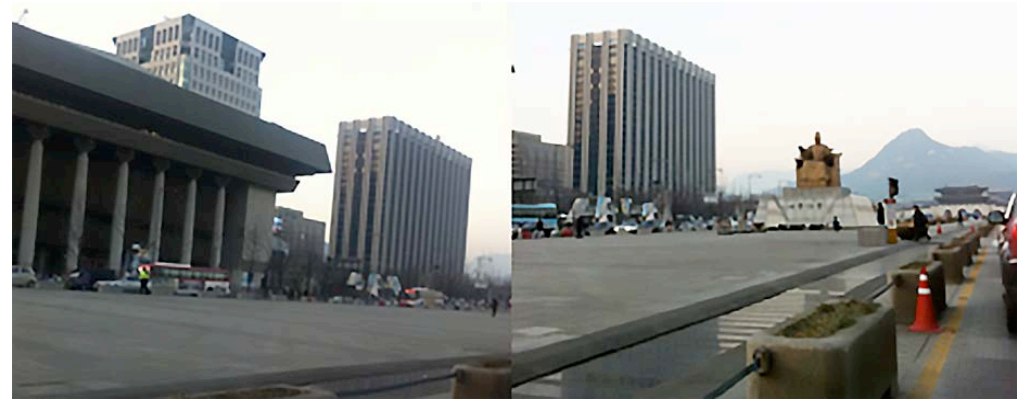

Figure 11. Sejong-no (below) (Source: Author, 2012). 
they give a great sense of character and identity for a city, and offer the chance for surprise discoveries for visitors".

Another user commented "I prefer this as I like undulating and hilly towns more that flat ones. I get a better sense of place when I can review the hills around."

This rooted cultural and social activity stands in contrast to the new development along the boulevard of Sejong-no, the large central strip of public, pedestrian-only space is currently underused and lacking in this activity and vitality. It is the view of certain planners, such as those overseeing the development of the central boulevard in Putrajaya, Malaysia, that informal usage and creative occupation of public space along central boulevards serving public offices is inappropriate (Choi, 2011). The planners of Putrajaya feel that the central boulevard should be reserved for national festival activities. However, there is a danger that this reserved approach to place-making becomes, to quote Stern and Hall (2010), "disassociated from current residents, their needs and activities, and the infrastructure that supports those needs and activities." The feedback from the 21 participants in the interview process, including members of the Seoul planning department, have revealed how the urban policy for each region is only geared towards commercial growth and increasing the international competitiveness of each region, rather than focusing on localization.

Frampton (1985) argued that modern architecture should engage with and respond to its particular context, in order to revive the old and enrich the new, resulting in an evolving and sustainable sense of place identity.

In essence, the importance of public space is a political concern, but there is a growing body of evidence that public space also provides a range of benefits across economic, cultural and environmental spheres. One of the key historical changes facilitating the rise of the public sphere is the increasing differentiation of society and particularly a separation of political authority from the sphere of everyday and domestic life. In a semi-structured interview with the key decision makers from the planning department, the respondent (2012) mentioned that “..the government's top-down approach to policy-making and policy implementation is common. Recently, a committee has been organized as a local autonomous entity to proceed with their urban development by giving an autonomous strength, especially for the democratic urban policy-making process, but there exists no clear role to control the committee. Therefore, undemocratic and political lobbying arises without the participation and engagement of the community." This relates to new place-making and the maintenance of the culture and vitality of a region. R. King (2009: p. 616) argued that, in Korea, "new cultural production is overwhelming either pastiche or electronic; political activity slips from the Third Estate of popular democracy to an emerging Fifth Estate of the Internet and the weblog. Particularly, in Korea's case we may have the paradox of the weakly defined nation slipping away, into a wider imagined community, even as the dream of Korean distinctiveness cuts ever deeper." 


\section{Defining Disappearance}

Understanding the urban changes in Korea in terms of sustainable national and local identity, there are applicable lessons to be learnt from the architectural typology of the government buildings within Seoul.

Since independence from Japan in 1945, the seat of Seoul's city government has been the City Hall building (see Figure 12, in foreground), a gothic revival building that was built during the period of Japanese rule. The classical details of columns and portico echo the traditional hierarchy that still exists within the successive "republics" of South Korean rule. A recent addition to the government buildings in Seoul is the new President's office (see Figure 12, in background). The existing colonial building retains a rooted sense of place whilst the new addition represents a future-orientated approach to providing a new identity.

The interpretations of such identities in architectural built form are connected to the wider issues of society and the public realm, and at a more intimate level relate to materiality and human experience. In a semi-structured interview with Lim, a local resident, when questioned about the changing usage and perception of the area, she commented "I have been living here since the Korean-Japanese War. Some of the local housing has been converted to hotels and many tourists come to see our traditional way of life and atmosphere. The way we live our lives is how it has been for generations." These comments highlight the particular sense of place that exists within Seoul.

In addition, cultural identity includes social activities that provide relationships between public space and users' activities, enhancing a sense of place. In Seoul, there are many cultural and historical events, festivals and public performances, engaging inhabitants and visitors and encouraging their participation. From the workshop meeting with Seoul residents these events and festivals were highlighted as a key element of the city's identity.

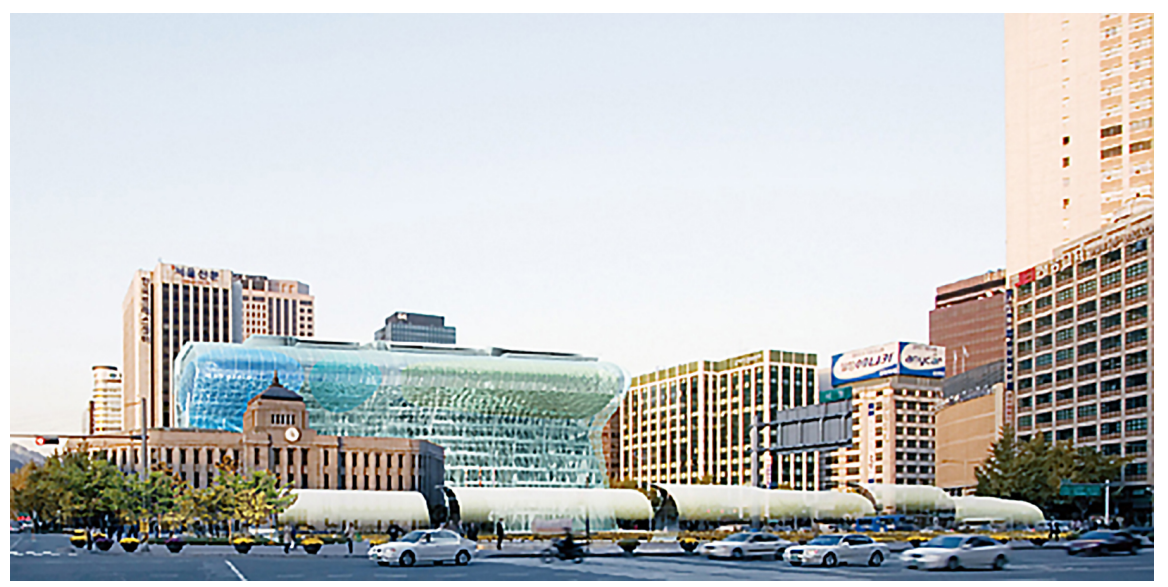

Figure 12. Old and New City Hall in Seoul (source: Seoul Metropolitan Government, 2010). 
The participants further stated that the retention of historical and memorable built form in urban development is something they valued. Especially, the retention rather than demolition of heritage buildings can embody users' memories and sense of time and place, encouraging an evolving form of cultural usage and activity and informing the creation of a particular kind of local identity. The spatial analysis and assessment of cultural activity shown in Figure 13 illustrates how the traditional built form of the Old City Hall and the contemporary New City Hall have been supplemented by a new form of public space to the south, within which space has been reserved for evolving forms of cultural usage.

This understanding of the local identity of Seoul urban development highlights how the new design approaches to the area are concerned and focused with the creation of the hard tissue of building form within the context of the soft tissue aspects of cultural identity and community engagement, in order to emphasise continuity, distinctiveness, and self-esteem (Twigger-Ross and Uzzell, 1996),

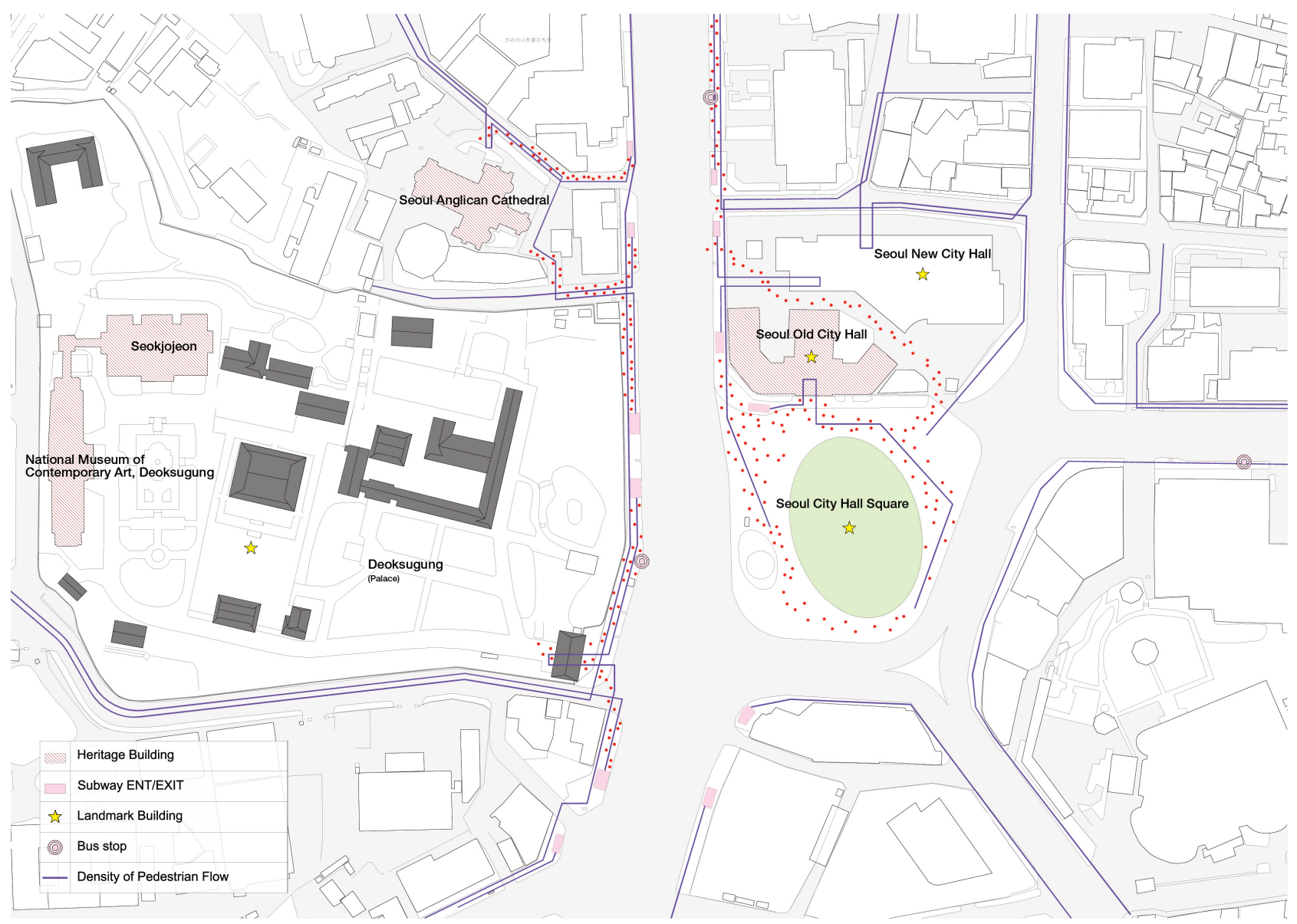

Figure 13. Samcheong-dong: Spatial analysis with cultural activity (Source: Choi and Lee, 2012). Note: This figure shows the extensions of cultural usage within the context of heritage and government building and in relation to new forms of public space, with an evolving building typology from the Old to the New City Hall building. The density of cultural usage between the City Hall and public space and defined by the Heritage (landmark) buildings and its neighbourhood represents how this new form of public space can provide a social and cultural network that maintains a tension between the history and contemporary life of the area. 
based on historical, social and cultural contexts.

This research illustrates the characteristics of human attachment to the built environment, particularly in relation to the Samcheong-dong and City Hall area of Seoul, from which transferable positive and negative lessons can be drawn for establishing place-identity. This research has provided a better understanding of how local traditions and contemporary design ideology can be reconciled in place-identity terms. Kevin Lynch (1960: p. 104) argued that the "practical" and "aesthetic" functions in complex built form are inseparable, and that physical patterns may have predictable effects in culture, with its value and social structure.

\section{Conclusion}

Reviewing the sustainable environmental, social and cultural urban development taking place, it is important to give consideration to the new forms of public space and place identity being created in response to global forces or transnational urban changes.

A critical understanding of the urban transformations of the public open space around Sejong-no, including the demolition of the colonial Governor General Building and the creation of a pedestrian friendly environment, gives a transferable lesson when considering the tension between political power and socio-cultural space in place making.

The evolution of the cultural and political identity, street pattern and the natural landscape within Seoul in particular highlights the way in which the new place making can be established and commence its own period of evolution. As the political identity of the government seat in Seoul shifts from a traditional identity to something new and less identifiable, the new public space created can sustain and evolve local identity only if it can be accepted and understood by residents and users in relation to their social and cultural context and structure. This shows the importance of how changes in the economic system and the political system influence the transformation of cultural institutions and practice in place making (Rapoport, 1977).

The local identity created is not that of a fixed, perfect state but rather an evolving one that responds to changes in the form production process in relation to its social, cultural, and political context in each city. The value of local identity in the development of a city's social structure and physical form is an important and evolving part of urban design thinking and ideology, in relation to the value of locality and social and cultural context.

As discussed, place-making is defined not simply in terms of physical aspects, but also through an understanding and appreciation for cultural processes, whereas the creation of local identity can be clearly interpreted as a political act, not inspired by a desire to create a particular sense of locality but by political ambition.

Considering that, it is worth analyzing the tensions of such practices, as the 
interrelationships between historical spatial structure, human perceptions and social patterns, so that an appropriate balance of usage can be achieved, the area's unique character maintained and a diverse new range of cultural activities sustained.

In closing, this paper has helped to explain how the case of Seoul can contribute to the establishment of local identity for 21 st century contemporary urban development in South Korea and the wider Asian region. This stresses that in place making it is crucial to acknowledge the cultural, political, and economic context, in order to create not only distinctive design qualities with sustainable built form, but also a progressive design ideology and an evolved urban design framework for a "better loved", forward looking, locally and globally sustainable city.

\section{References}

Abel, C. (1997). Architecture and Identity: Towards a Global Eco-Culture. Oxford: Architectural Press.

Appadurai, A. (1996). Modernity at Large: Cultural Dimensions of Globalization. Minmeapolis: University of Minnesota Press.

Choi, H. S. (2011). Transcription Files in Possession of Place-Identity in 21st Century New Town Development. Ph.D. Dissertation Appendices, Oxford: Department of Built Environment, Oxford Brookes University.

Frampton, K. (1985). Modern Architecture-A Critical History. London: Thames and Hudson.

Fraser, N. (1992). Rethinking the Public Sphere: A Contribution to the Critique of Actually Existing Democracy. In C. Calhoun (Ed.), Habermas and the Public Sphere (pp.109-142). Cambridge: MIT Press.

Harvey, D. (1990). The Condition of Postmodernity: An Enquiry into the Origins of Cultural Change. Oxford: Blackwell Publishing.

Kernbeisser, K. (2010). Bank of Korea.

https://www.flickr.com/photos/kernbeisser/3075738499/in/photolist-5FMXU8-RfFoMj -q98gtG-6PenZv-VBq8ux-SHbwdQ-8cGcZK-s6nSt-VtttzL-U5SGHW-9J2yaS-9HZ3Yk -6tKpWo-6jZMQ7-9HYAUv-5LbMPm-VBq9or-s6o7j-HjV8eF-VBq3KH-V2fjxh-6jVD qK-V2fK6S-fpAMo3-5kuRC3-93D5o-VBq6Mz-8VCX1k-6jVJMZ-baAPK-5FS85G-7s7 Aeh-skMg1W-9jwceT-U8q44k-Uipy6n-Ui6as2-fuDXoN-hjJT9N-abCwRX-WebpEq-7t owUA-baANE-s6o4S-VBq6DD-KvjZR-5LbMK9-baAPt-cNoScN-8dzEbP

Kim, B. (1991). Openness and Cultivation. Seoul: Moonji Publishing.

Kim, D. C. (2013). https://pixabay.com/en/users/olmusician-2219832/

King, A. D. (2004). Spaces of Global Cultures: Architecture Urbanism Identity. London: Routhledge Publishing.

King, R. (2009). Seoul, Conditions of Possibility, and the Postnational Hyperspace. Environment and Planning D: Society and Space, 27, 616-632.

https://doi.org/10.1068/d5908

Lee, M. H. (2012). Seoul Map Analysis and Analysis of the Public Usage. Seoul: Seoul National University.

Lynch, K. (1960). The Image of the City. Cambridge, MA: MIT Press.

McDowell, L. (Ed.) (1997). Undoing Place. New York: Wiley. 
Mitchell, D. (1995). The End of Public Space? People's Park, Definitions of the Public and Democracy. Annuals of the Association of American Geographers, 85, 108-133.

Park, H. S. (2017). Sejong-No. https://www.pinterest.com/pin/157696424422525786/

Rapoport, A. (1977). Human Aspects of Urban Form: Towards a Man-Environment Approach to Urban Form and Design, Urban and Regional Planning Series 15. Oxford: Pergamon Publishing.

Seon, J. (2003). Seoul Urban Development. Seoul: Hanul Academy Press.

Seoul Metropolitan Government (2010). Seoul History. http://www.seoul.go.kr/

Stern, P., \& Hall, P. (2010). Historical Limits: Narrowing Possibilities in 'Ontario'S Most Historic Town'. Canadian Geographer, 54, 209-227. https://doi.org/10.1111/j.1541-0064.2009.00296.x

Twigger-Ross, C. L., \& Uzzell, D. L. (1996). Attachment and Identity as Related to Place and Perceived Climate. Journal of Environmental Psychology, 25, 207-218.

Werbner, P. (1998). Negotiating Public Space: Strategies and Styles of Female Domestic Workers in Singapore. Urban Studies, 35, 583-602. https://doi.org/10.1080/0042098984925

Whyte, W. H. (1980). The Social Life of Small Urban Spaces. Washington DC: Conservation Foundation.

Yoo, S. (2010). Views of New Public Space Sejong-No and Gyeongbok Palace, Korea-Japan 100 Years on-Efforts to Correct Wrongs Done by Japanese. Seoul: Korean Herald.

Zukin, S. (1991). Landscapes of Power: From Detroit to Disney World. Berkeley, CA: University of California Press.

Submit or recommend next manuscript to SCIRP and we will provide best service for you:

Accepting pre-submission inquiries through Email, Facebook, LinkedIn, Twitter, etc. A wide selection of journals (inclusive of 9 subjects, more than 200 journals)

Providing 24-hour high-quality service

User-friendly online submission system

Fair and swift peer-review system

Efficient typesetting and proofreading procedure

Display of the result of downloads and visits, as well as the number of cited articles

Maximum dissemination of your research work

Submit your manuscript at: http://papersubmission.scirp.org/

Or contact cus@scirp.org 